\title{
瀬戸内海国立公園・下津井亡牛空の風景準備
}

\section{Preparation of Landscape in Shimotsui and Ushimado on the Nomination for National Park}

\author{
小野 芳朗* \\ Yoshiro ONO
}

\begin{abstract}
In 1934, an area of Seto Inland Sea was nominated as National Park depended on the "discover" of the view from the top of the mountain, Mt. Washu in Shimotsui-cho by Dr. Tsuyoshi Tamura et al. However, the panoramic view from the top was prepared by Shimotsui-cho government and Shimotsui Train Co. Ltd. There is a leaflet on the view of the top of Mt. Washu published by the Shimotsui Train Co. Ltd. before the visit of Tamura. The view of the top can see around the whole area of Bisan Seto, islands and running ships. It was the discovered landscape by Dr. Tamura, but also prepared one by the local government and other stakeholders. Ushimado-cho government also prepared the landscape from the top of a hill, Kameyama that was developed as a view point. Dr. Tamura did not adopt the landscape and estimated not to be panoramic view. This paper discuss on the performance of the Committee of National Park represented by Dr. Tamura and the preparation by the local stakeholders.
\end{abstract}

Keywords: National park of Seto Inland Sea, Simotsui, Mt. Washu, Usimado, Dr.Tsuyoshi Tamura キーワード：瀬戸内海国立公園, 下津井, 熟羽山, 牛空, 田村剛

\section{1.はじめに}

瀬戸内海国立公園は昭和 4, 5 年 $(1929,30)$ の熟羽山の「発 見」によって確立したとされる。そこからの眺望である「多島海 の発見」は, 東京帝国大学教授・理学博士の脇水鐵五郎と内務省 嘱託・林学博士の田村剛によるものであった。山上からの眺望景 観という新しい視点がつくられ，それが瀬戸内海国立公園の核心 となった説 ${ }^{1)}$ は妥当なものと評価してよい。熟羽山の「発見」 をなした田村剛の論説には, 大正 10 年（1921）時点では瀬戸内 海を「海上公園」として, 島々を船でめぐって「遊行」する公園 とみていることから ${ }^{2)}$, その後の山上展望という熟羽山の「発見」 は画期的風景観の転換であったといえよう。当初，小豆島と屋島 地域のみであったものは備讃瀬戸海域に拡大される。脇水はその 著，『日本風景誌』3) の中で昭和 4 年（1929）に熟羽山からの眺望 を「発見」し，翌年田村屯熟羽山に登り，その絶景に国立公園の 核心を得たとされる ${ }^{4)}$ 。瀬戸内海国立公園は, 同様に王子ヶ岳, 十禅寺山, 御獄山, 高無坊, 白石島, 仙酔島の山上からの視点場 が設定されて成立した。

従来の研究が, 国立公園設置を内務省サイドより見て「新しい 風景の発見」として捉えることは十分に根拠のあることではある が，一方で指定された地元側の風景の準備はどのようなものであっ たろうか。本論文では国立公園を決めた脇水, 田村の所属した国 立公園委員会側の視線之, 地元の県や町の視線の双方を検討する。 脇水や田村によって「発見」された風景, 山頂からの眺望「大観」 は，地元で準備された風景であった。その眺望の国立公園指定の 是非は田村の「大観」に沿って決められた。その事例を岡山県下 津井, 牛空を対象に, その町の所蔵資料である「町会会議録」や 「国立公園関係文書綴」に加え,「山陽新報」の記事をあわせなが ら実態を描いていく。

\section{2. 下津井鶰羽山の発見亡準備}

西田正憲の指摘する昭和 4 年の脇水と翌 5 年の田村の熟羽山の
「発見」は，彼ら調查団側としては事実であり実感であったとい える。昭和 7 年 (1932） 4 月に国立公園候補地視察委員一行 12 名が鷲羽山を視察して，国立公園編入への道が確定するが，これ は国府犀東や脇水，田村の「発見」があったからである。昭和 4 年（1929）に国府と脇水は熟羽山に登った。西田論文には脇水の 「発見」として「昭和四年の夏 (中略) 熟羽山に登り, 偶然にも 同所が展望台として上揭の諸条件を具備する絶好の地點たるを發 見し」とある ${ }^{1)}$ 。また同論文における田村の「発見」は，その言 質を『岡山県史蹟名勝天然記念物調査報告』 ${ }^{5)}$ に拠っている。こ こに田村の講演として「創立五十周年記念岡山縣青年会」なる書 に「熟羽山に登つた。そして私は意外な絶勝を發見して暫くはう つとりとして無言でいた」と劇的なその「発見」を引用してい る ${ }^{1)}$ 。

しかしながら原典を注意深く読むと以下のような記述がある。 まず脇水の『日本風景誌』には, 「昭和四年の夏, 筆者が岡山想 下津井町の六口島の象岩を調査に行つた時，町長の案内にて町の 東にある熟羽山に登り，偶然にも」とある ${ }^{3)}$ 。また田村の言質を 引用した前掲書の田村発言部分は「(前畧) 熟羽山に登つた, そ して私は意外な絶勝を發見して」とある。この（前畧）された部 分には原典の『第廿七回会報 創立五十周年念号 昭和五年十二 月 岡山縣青年会』に「此間久しぶりで，香川縣の坂出町から小 艇に乗せられて瀨戸内海を横断して下津井に上陸したがこつで 保勝会の人々に迎へられて, やはり駕籠て鷲羽山に登つた。そし て私は意外な絶景を発見して」 ${ }^{4)}$ とある。以上の事実は脇水や田 村の「発見」の前提に, 地元下津井の準備があり, また熟羽山眺 望は知られた存在であったことが示唆される。

その傍証として，ひとつには昭和 2 年（1927）指定の「新日本 八景」中に百景のひとつとして下津井が選定されていること，そ の審查委員に国府, 脇水, 田村がいることがあげられる ${ }^{6)}$ 。また 脇水の昭和 4 年の「発見」は, 町長の案内とあるが同行の中に, 下津井町役場の高本恭夫がいたことが知られている ${ }^{7)}$ 。高本は熟

*京都工芸繊維大学大学院建築造形学部門 


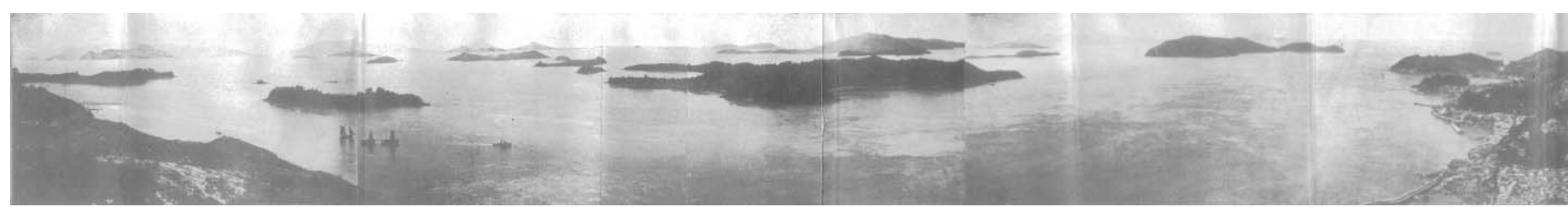

図－１『下津井鉄道名所図絵』掲載の熟羽山眺望写真

羽山の考古学的調查を早くから実施していたとされ, 前掲の『岡 山県史蹟名勝天然記念物調査会報告』に「下津井鹑羽山」の原稿 を書いた ${ }^{5)}$ 。そこには「内海風景として代表的景色を一睡の下に 大観しうる地点」之記され, その風景の特徵を山頂から白帆の浮 かぶ青い海に東は小豆島, 西は神島白石島あたりまでを一望にみ わたせると表現している。この高本の存在が脇水を熟羽山へ誘っ た。そして昭和 5 年 11 月 19 日に熟羽山は国府, 脇水が属する史 跡名勝天然記念物保存協会 ${ }^{6}$ により名勝指定される。田村の「発 見」は，この指定日のわずか 8 日前の 11 月 11 日である。田村の 登頂がそれが初めてであり，その「発見」自体は事実であったと しても, 新日本八景の選考委員として, また史蹟名勝天然記念物 調査の情報を通して, 鷲羽山眺望の情報は関係者で共有されたと 考えられる。

またその眺望を準備した地元の存在が考えられる。この昭和 5 年の田村登頂時に案内した「保勝会の人々」の実名は明らかでは ないが, 昭和 7 年 (1932） 4 月 17 日の下津井訪問の国立公園候 補地視察委員会 $(\text { 藤村義朗委員長 })^{8)}$ の下津井訪問を迎えたメン バーは, 久郷梅松岡山県山林課長, 内藤富五郎町助役, 三宅義路 下津井海岸保勝会幹部, 篠原英太郎県知事属官などで, これに加 えて下津井鉄道関係者が, 秋山文治郎下津井鉄道専務, 永山久吉 県会議員 (後に 2 代目社長), 吉福嘉一郎町会議員（下鉄の株主） が入っていた。ここに脇水や田村, その後の藤村委員会を誘導し, あるいは候補地を準備した stakeholders を推測することができ る。それは岡山県, 下津井町, 下津井保勝会, そして下津井鉄道 である。

下津井保勝会は, 昭和 3 年 (1928) に組織され, 毎年下津井町 から 50 円から 500 円の補助がなされていたが, 昭和 7 年は 5 度 にわたり合計 1700 円の補助がだされている ${ }^{9)}$ 。保勝会の会長は 町会会議録（昭和 7 年 4 月 25 日）によると, 町長が兼任するこ とが決められている。つまり実質下津井町の直轄運営組織であっ た。昭和 7 年 10 月 8 日に 12 箇所の国立公園正式候補地の中に選 定されると, 保勝会は 11 月 6 日には祝賀会を挙げている。この 報道が山陽新報によってなされ，「天下無敵を誇る大展望台，熟 羽山」の見出しで「この天然の玉峰を世に出すべく必死の運動を つづけ, 中にも保勝会の幹部は自費を投じて涙ぐましいまでに東

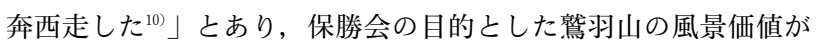
「大展望台」「天然の玉峰」であり, そこからの「大観」を目指し たことが窺える。

また, 熟羽山視察に出迎えた岡山県の官吏久郷梅松は東京帝大 林学実科卒業で, やはり東京帝大林学卒の田村の先輩であった。 大正 10 年（1921）に田村が岡山後楽園を名勝指定の為に岡山を 訪れた際, 西外園の設計を県が委託した。その時, 植木調達を担 当したのが山林課長の久郷であった。そして大正 15 年 (1926) 7 月 1 日後楽園の管轄が県内務部地方課から山林課へ移行した際 に, 職掌として後楽園事務所長を兼任している。昭和 9 年 （1934）室戸台風の復旧工事設計を田村に委託したのも当時まで 事務所長を務めた久郷亡考えられるなど, 後楽園を通しても久郷 と田村は関係が深かった。久郷はさらに岡山県国立公園協会常務 理事を兼ね, その設置事務の中心にいた。田村の熟羽山への直接 の誘導に久郷が関与したという確証は得られていないが，このよ
うな人物が，県国立公園協会常務理事として情報提供源のポジショ ンにいたことは事実である。地元の「大観」の準備の上にこうし た人脈が働いたと推測できる。

さらに鷲羽山眺望の開発とそこへの誘導は下津井鉄道の役割が 大きい。下津井保勝会の会長を昭和 9 年より務める下津井町長永 山久平の一族, 永山久吉は下津井鉄道の 2 代目社長となる。下津 井鉄道は, 明治 44 年（1911）軽便鉄道として回船業者や肥料問 屋の出資によるもので, 下津井-丸龟間の四国連絡航路の維持の 為, 内陸都市への交通手段として建設された ${ }^{11}$ 。その下鉄は昭和 の初期, 恐慌による不況のため経営不振に陥っていた。永山の回 想録に田村が文を寄せ，「下鉄がただ一般乗客と荷物の輸送だけ では経営がうまくないので, この天下の絶景熟羽山という, 眠れ る観光資源の活用を思いつかれ，それにより会社が立ち直った」 といっている ${ }^{12)}$ 。その回想録には永山が昭和 6 年 (1931) に鷲羽 山の眺望を利用して乗客を誘致することを思い至ったという ${ }^{13)}$ 。 しかし既にその眺望は下津井鉄道自身が「開発」していた。昭和 3 年に発行された『下津井鉄道名所図絵』には,「鷲羽山の大見 晴し」として四国側より下津井から熟羽山, 唐琴, 渋川の海岸ま でを描いた鳥瞰図が存在する ${ }^{14)}$ 。またその董面には熟羽山山頂よ り見渡した備讃瀬戸中の島々のパノラマ景の写真が掲載されてい る(図-1)。すでに熟羽山絶景は昭和 3 年時点には地元で知ら れ，鉄道会社による「開発」により宣伝もなされていたことがわ かる。このパノラマ景の写真の構図は, 高本恭夫による昭和 7 年 の『岡山県史蹟名勝天延記念物調查報告』中の掲載写真とアング ルがほとんど同じである（光陰は異なるので別写真）。こうした 熟羽山山頂のパノラマ景観は, 早くから下津井には「開発」され ていた視点場であったと推定できる。

以上のように下津井鷲羽山の脇水, 田村による「大観」の「発 見」が国立公園指定の核心となることは事実ではあるが，そこに 至るまでは「大観」の準備が地元, 下津井保勝会（すなわち下津 井町）と下津井鉄道によってなされ，その準備の上に新日本八景 指定での同僚委員からの情報, あるいは岡山県官吏との関係など が絡んで, 昭和 5 年の「発見」に繋がったとみることができる。

\section{3. 牛空亀山公園の準備と視察}

牛空も瀬戸内海国立公園に昭和 9 年当初より指定されるが，そ の指定をめぐっては下津井のように眺望景観, 「大観」を準備し たつもりであったが，それは田村の考える「大観」には適わなかっ たようだ。

『牛空町史』 ${ }^{15)}$ には，昭和 8 年（1933） 4 月 11 日と 5 月 22 日 の山陽新報を引用し,「運動の如何によっては, 従来とり残され てるた牛空附近の景勝地も, 内海国立公園の圈内に入れられるこ とは想像に難しくなく」あるいは「牛空・笠岡の明朗な景観は, 他との振合を考慮されて今回は内海公園区域内に包含されぬこと になっている模様である」とあり, 熟羽山等展望地以外の笠岡諸 島と牛悹は昭和 8 年時点でも区域内に入っていなかった可能性が 高かったとしている。

国立公園指定へ向けての推進の母体となったのは，牛空商工会 と牛空保勝会である。牛空商工会は明治 41 年（1908） 1 月 10 日 に設立，第 1 期役員には理事長に石井卯次郎，理事に高祖吉三郎 
以下 7 名の名がみえる ${ }^{16)}$ 。それによると,「明治の初年頃迄瀬戸 内海に於て屈指の商業地として雄飛せし牛空港も山陽鉄道の敷設 等の影響を蒙り, 年々衰頽の一路を辿り日露戦後の経済界大反動 に遭遇して疲弊一層甚だしきを加へたり」とあり, 町勢挽回を期 しての結成であった。牛空保勝会は名所旧蹟の保存につとめ, 昭 和 2 年（1927）には明治 20 年開設の海水浴場の経営を始める。

海水浴場東端の丘の上にある龟山公園は牛空における展望地と して整備された。早くも大正 10 年 (1921)，新聞では「奇松の点々 とした様な内海を隔て〉讃岐の連峰が屏風を立てたやうに南を囲 んで, 東に播磨灘を望み, 往き復る真帆片帆漁船が浪に摇られて るる様 ${ }^{17)}$ と記している。田村はこの時点で牛空を景勝地とは認 識している ${ }^{18)}$ が，眺望景観があると知っていたのかは明らかでな い。少なくとも牛空の眺望に関する記述はない。

年代不詳ながら戦前の亀山公園の設計図面が牛空町資料中に残 されている ${ }^{19)}$ 。公園は八幡神社（牛空神社）に至る参道の中途に 作られた。そして牛空商工会は, 会長に高祖鶴雄（代表的な地主 一族, 造り酒屋) を迎える ${ }^{16)}$ 。高祖鶴雄は商工会会長として国立 公園誘致に尽力したのち，のちに町長に転出する。

昭和 7 年 4 月の候補地視察委員会は牛空を訪れていない。その 編入要請を牛空商工会が運動した形跡がみられる ${ }^{20)}$ 。昭和 8 年 （1933） 4 月，瀬戸内海国立公園の区域決定調查に田村剛一行の

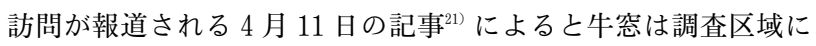
入っていた。4月 13 日の役員会において区域内編入を期すべく， 「国立公園委員」を県当局に派し, 一行の調査プランを作ったと ある。その概要は「眺望の好き亀山公園, 西寺, 吉田山等に案内 して波に煙る阿讃の諸島の絶景」とあり, 展望の視点と多島海を アピールする田村好みの風景が用意されていた。山陽新報の記事 には，5月 2 日に岡山駅に到着した田村に, 牛空町長, 笠岡等関 係町村長が, 名所案内, 景勝写真等を差出し視察日程に繰入れる よう猛攻撃をなした，とある222。

そして田村一行は小豆島から牛空に到着する。この「田村一行」 の瀬戸内海区域決定（追加）調査は, 昭和 8 年 4 月 16 日から 5 月 31 日にかけて行われるのであるが, 田村とその随行が全員一 緒に動いていたのではない。その詳細「予定」が牛空町資料に残 されている ${ }^{23)}$ 。先発隊の内務省加藤技手, 黒田技手, 戸坂技手が 屋島, 庵治, 五剣山, 小豆島, 豊島, 直島をまわる。田村が屋島 で合流し, 鳴門海峡, 小豆島の後, 牛空にはいる予定であった。 その後, 一行は宇野から備讃諸島, 塩飽諸島, 笠岡諸島に至り, 倉橋島から広島に上陸する予定であった。田村の上陸ののち, 加 藤, 黒田, 戸坂の 3 名は再び調査に戻る。この昭和 8 年の田村の 調査は, すでに「発見」した展望地の調査ではなく, どの区域を 編入するかという田村の意思決定のために実施されたと考えられ る。

実際には 5 月 2 日に岡山駅に到着した田村は，阿波鳴門，高松， 小豆島を経て, 牛空には 5 月 6 日に入った。牛空の調查はこれ一 回きりであった。昭和 8 年 5 月 6 日午後 3 時田村一行は小豆島を 出港し ${ }^{24)}$, 牛空湾に浮かぶ前島, 鼠島, 青島, 黄島を視察, 6 時 に牛空港に上陸し, 照月旅館（当主 : 菊田加代）に入った。照月 旅館においては 6 日夜 9 時からの座談会がもたれた。牛空側から 津島警察署長, 小橋廣衛町長, 川崎小学校長, 高祖鶴雄商工会会 長 (観光常設委員 $\rightarrow$ 公園設置委員), 森照二商工会評議員 (公園 設置委員 $\rightarrow$ 土木常設委員) 以下, 町会議員, 商工会役員 23 名が 集った。これに岡山県の次田守岡山県山林課技手（岡山県国立公 園協会技手, のちに県史跡名勝天然記念物調査会嘱託）之藤田保 健課長が加わっていた。高祖や森のように商工会役員でありなが ら町の常設委員を兼䄈る者もあり, 牛空町が官民一体となって誘 致していた陣容がうかがえる。田村は牛悹については「牛空が釣 の名所と云ふ事は聞いたが，それらの事も公園の利用方法の内に
入れる必要のある事だらう」と言い, 眺望地については発言して いない2 ${ }^{25)}$ 。明くる 7 日, 問題の亀山公園に登り, その後黒島, 中 小島，端小島を見てのち，児島郡小串港へ向かった。

ところがその後の田村の発言は牛空に肯定的ではない。調査を 終え, 5 月 16 日午後 5 時 19 分広島より岡山駅に降りた田村への 記者団の質問で，「岡山県下では王子ヶ獄，白石島あたりは見逃 すことが出来奴之語る。いずれも「大観」を有する眺望地の認 識であった。しかし牛空については，「大體において区域は内定 してるるところ以上に新らたに擴げることは仲々困難である。岡 山県下では牛空，宇野，王子ヶ獄などを新らたに視察したがその 結果についての意見は遺憾ながら申上げる訳にはいかない26)」と ある。つまり今回の調査は「内定」している区域の確認に加え， 新しい箇所がないかを調べたもので，よほどでないと容れ難いと いうものであった。またおそらく5月 17 日昼間におこなわれた であろう（16 日は午後七時半より岡山一中同空会， 17 日午後 5 時 25 分発岡山駅から帰京), 岡山八番町の田村の自邸における記 者座談会で, 記者に「牛空の龟山八幡から指呼の間に点緅する前 島鼠島黄島黒島などの美景は?」と問われ, 対して田村は「却々 捨て難いものがある…… (新聞の記載のママ)」と言葉を濁し ている ${ }^{27)}$ 。この 2 度の記者取材と田村の牛空編入への消極姿勢が 前述した 5 月 22 日報道の「今回は内海公園区域に包含されぬこ とになってるる模様」につながったとみてよい。牛空の龟山公園 の眺望に対する言及は皆無であった。

これに対して牛空町は県と協力して巻き返しにでる。それは眺 望景観に頼ることをやめ，島嶼部の指定に照準を合わせたもので あった。県技手次田より 5 月 29 日牛空町長小橋宛に「先般田村 博士御来県 $\ni$ 機トシ県会議事堂二於テ国立公園施設二付打合有之 候件二関シ関係町村ノ御希望事項 7 取纏入本県へ具申致度候」 ${ }^{28)}$ とある。これに対応して小橋町長が内務大臣山本達雄宛「国立公 園区域認定請願書」をまとめたのが 6 月 10 日である。その請願 書には「田村博士ノ御踏查ヨ経夕ル處有之町民挙ツテ其ノ編入 熱望シ之ガ為メ二八相当ノ犠牲ヨ払フヨ敢テ辞セザル決心二有之 候。是非共区域中二御決定被下度別紙町会決議書写並二調查書類 相添此段請願候也 $ل^{28)}$ とある。その町会決議書とは，「国立公園区 域認定二関シ必要ノ場合八黒島其他ノ島嶼二散財セル私有地 7 買 収シテ町有トナシ将来其筋ノ施設経営二対シ異議無キモノトス ${ }^{28)} 」$ とある。添付の調査書には景勝地や交通・人口・施設の有無など 牛空の詳細な現勢とともに, 町の予算決算ならびに前島など島嶼 部における土地台帳の写しが添付されている。その地主の筆頭は 高祖徳三郎である。

こうした挽回への牛空町と岡山県の運動は, 結果的に功を奏し た。昭和 8 年 11 月 10 日の内務省国立公園委員会に向けて, 岡山 県が「新たに編入かたを申請した邑久郡牛空および児島郡山田村 地内出鼻の牛島は何れも編入予定区域に追加提案されることになっ た よ゙) とある。

結局, 国立公園には牛空の島嶼部が編入される。11月 30 日の 国立公園委員会で田村はこう語る ${ }^{30)}$ 。「此二牛空町附近ノ島嶼ガ アリマス此辺一体八除外サレテ居リマシテ（今回編入されたの で:籍者注) 海面八相当広クナリマシ夕」「牛空附近デ八前島, 黄島, 黒島, 青島卜言フヤウナ此辺一帯ノ島嶼八, 当初ノ区域 7 拡張致 シマシタ結果当然新二区域二編入セラレマシタ」。そして昭和 9 年, 国立公園設置のための調査団が来る。2 月 22 日, 加藤技手と 嘱託稲垣龍一が牛空町に入り, 23 日前島, 24 日豊島, 25 日黄島, 鼠島に「杭打ち」を行った ${ }^{31), 322}$ 。

亀山公園は区域に入らなかった。牛空が当初区域から漏れたの は，牛空町が準備した亀山公園八幡社が，内定している熟羽山や 白石島のような展望地に比べて，視点場の高さが低いことや視界 が開けるという点においては劣るという田村の国立公園風景観で 
ある「大観」に欠けていたのではないだろうか。

\section{4. おわりに}

本論では, 下津井熟羽山と牛空亀山公園を瀬戸内海国立公園へ の編入過程を比較した。以下本論で明らかになった点をあげる。 まず下津井である。

1) 下津井熟羽山の情報は昭和 2 年指定の新日本八景で百景に指 定されることから, 選考委員の国府犀東種徳, 脇水鐵五郎, 田村剛に入っていたと考えられる。

2) 昭和 4 年に国府と脇水を熟羽山の山頂に誘導したのは下津井 町役場で『岡山県史蹟名勝天然記念物調查会報告』に「下津 井熟羽山」を「大観」と著した高本恭夫であった。

3 ）国府之脇水は史蹟名勝天然記念物保存協会のメンバーであり, 熟羽山は昭和 5 年 11 月 19 日に名勝指定される。

4 ) 田村は同年同月 11 日に下津井保勝会の人々に迎えられて輿 に乗せられて鷲羽山に登頂する。

5 ) 下津井保勝会会長は町長が兼任し, 町費で運営する実質下津 井町の組織である。

6 ）昭和 7 年藤村義朗委員会を迎えたメンバーから, その準備に は下津井町以外に岡山県と下津井鉄道が関与していた。

7 ) 岡山県官吏は久郷梅松山林課長で岡山県国立公園協会常務理 事を兼ねた設置事務の中心人物である。また田村と東大の同 門，岡山後楽園を通しての知己であった。

8 ) 下津井鉄道永山久吉社長は町長永山久平の一族（続柄は不明） である。昭和 3 年に熟羽山からの眺望写真を揭載したパンフ レットを作り，昭和 6 年に観光客誘致を発想する。

これに比して牛空の同時期の動向である。

1 ）亀山公園は大正 10 年には眺望地として整備されていたが, 同年の田村の記事には牛空は景勝地としてのみ記され, 眺望 についての言及はない。

2 ) 牛空商工会, 牛空保勝会が国立公園設置への運動を本格的に 始めるのは昭和 8 年田村訪問時と考えられる。

3 ) 昭和 8 年 5 月 6,7 日の田村の牛空訪問時に眺望景観として 亀山公園を準備した。

4 ）田村は登頂するがその眺望に言及せず，牛空の指定にも消極 的であった。

5 ）牛空町は岡山県とはかり, 照準を島嶼部に変更し, その編入 が認められた。

以上の事実から, 熟羽山眺望の情報は関係者に共有され, 下津 井町ではその眺望が準備され, 昭和 4 年から 5 年にかけての「発 見」はこの上に成立したとみてょい。その地元関係者は町, 下津 井鉄道, そして岡山県官吏である。実際に地元では海水浴場や宿 泊施設の準備も行われるが, 国立公園指定の核心は熟羽山の「大 観」への誘導であった。これに比して牛空は眺望地亀山公園を準 備はしていた。しかし田村の来訪した昭和 8 年時点で, 既に田村 の視線は鷲羽山の経験による「大観」が国立公園の視点場にふさ わしいとみなされ, 亀山公園の高さの眺望は適わず候補地指定そ のものから脱落しかける。

以上, 西田 ${ }^{1)}$ や堀 ${ }^{33)}$ が指摘しているように, 瀬戸内海国立公 園指定は「大観」の存在が国立公園としての資格と考えていたの ではないか，という推論を本論では強化した。指定の核心とされ る田村剛の「大観」は下津井町では準備され, そして「発見」さ れ, 候補地選定の基準となった。その視点場を準備できるか否か で指定の明暗が分かれたとみることができよう。
謝辞 : 本論の資料収集には岡山県立記録資料館, 岡山地方史研究 会金谷芳寛氏，下津井鉄道株式会社，倉敷市議会事務局，倉敷市 歴史資料整備室のご協力を得た。また岡山大学学生森大輔, 内田 英子, 伊藤乃理子の諸氏の協力もあおいだ。深甚の謝意を表しま す。

\section{引用文献}

1）西田正憲（1997）：瀬戸内海における多島海景の変遷と脇水 鐵五郎・田村剛の視覚：ランドスケープ研究 60(5), 425-430

2 ）山陽新報（1921）：9月 25 日

3 ）脇水鐵五郎（1939）：日本風景誌：河出書房

4 ）田村剛（1930）：「熟羽山」：第廿七回会報 創立五十周年 記念号, 岡山県青年会

5 ) 岡山県史蹟名勝天然記念物調查会編（1974）：岡山県史蹟名 勝天然記念物調査会報告第九冊（復刻版）：名著出版， 18-19

6 ) 高木博志 (2008) ：『史蹟名勝天然記念物』昭和編・解題： 不二出版

7 ) 山本慶一（1972）：熟羽山開発史：倉敷春秋，第 4 号

8 ）山陽新報（1932）：4月 19 日

9 ）下津井町役場（1929-1935）：町会会議録，昭和 4，5，6，7, 9,10 年の各年度簿冊

10）山陽新報（1932）：10月 23 日

11）青木栄一（1969）：下津井鉄道の成立とその性格：地方史研 究 19 巻 97 号, 45-60

12）田村剛「序して」（1958）:下記『下電と私』中にあり

13）永山久吉（1958）：下電と私：下津井電鉄株式会社

14）下津井鉄道株式会社（1928）：下津井鉄道名所図絵

15）牛空町（2001）：牛空町史通史編，1087-1088

16）牛空商工会役員名簿（1934）：備前牛空：牛空商工会

17）山陽新報（1921）：8月 17 日

18）同（1921）：9月 25 日

19）邑久郡牛空町役場（年代不詳）：亀山公園計画図面

20）山陽新報（1933）：4 月 16 日

21) 同 (1933)：4月 11 日

22) 同 (1933) : 5 月 3 日

23）邑久郡牛空町役場（1936）：国立公園関係書緅

24）山陽新報（1933）：5月 7 日

25）同（1933）：5月 8 日

26）同（1933）：5月 17 日

27) 同（1933）：5月 19 日

28）邑久郡牛空町役場（1936）：国立公園関係書綴

29）山陽新報（1933）：11月 1 日

30）国立公園委員会（1933）：昭和 8 年 11 月 30 日議事録 瀬戸 内海国立公園の誕生：環境庁 所収

31）山陽新報（1934）：2月 25 日

32）邑久郡牛空町役場（1934）：国立公園二関スル書類

33）堀繁（1994）：瀬戸内海国立公園の区域の取り方とその特徴 瀬戸内海国立公園の誕生：環境庁「田村博士の国立公園風 景観はパノラミックで雄大な「大観」にある。公園全体が見 渡せるような雄大な風景，つまり「大観」の存在が国立公園 の資格と考えていたのではないか。」 